\title{
Teachers' Attitudes Regarding Inclusive Education: The Albanian Case
}

\author{
Dr. Fatbardha Osmanaga \\ Department of Psyshology and Social Work. \\ University "Luigj Gurakuqi" of Shkodër Faculty of Education. Albania. \\ E mail: bardha_osmanaga@yahoo.com
}

\section{Doi:10.5901/jesr.2013.v3n7p76}

\begin{abstract}
Teachers'attitudes have considerable influence on the process of school integration of pupils with disabilities. Some data from contemporary literature show that the attitudes that teachers have about the process of inclusive education affects the quality of this process and the teaching quality. The impact of teachers'attitudes regarding inclusive education has, also, impact on pupils' attitudes toward their disabled peers. The paper aims to measure the attitudes of teachers in primary and secondary public schools of Albania toward manistreamming and the paper, aims, also, to analyze the influence of their demographic factors on their attitude. For the realization of this study it is used the technique of questionaire. The measuring instrument is the Mainstreaming Opinionnaire (MO) (Schmelkin (1981). Teachers of some schools of Shkodër, Lezhë, Kukës, Peshkopia, Tiranë, Durrës, Elbasan, Korçë and Vlora cities of Albania have completed the MO test. It is employed, also, the technique of interviewing teachers of public schools in which there are pupils with disabilities integrated and it is employed, also, the method of focus-group with teachers. The purpose was to obtain their opinions related to the problems that are encountered by them in the impemention of this process. There are given the appropriate conclusions and suggestions. It is necessary to consider certain recommendations so that the process of inclusive education is carried out completely.
\end{abstract}

Keywords: teachers'attitudes,inclusive education, MO test.

\section{Introduction}

The scholastic integration of disabled pupils is part of inclusion process. The main actors in the teaching process are teachers and students. It is considered necessary to measure teachers'attitudes about inclusive education as well as the examination of the relationship between demographic factors (age, gender, job position, teaching cycle, work experience) and teachers'attitudes about inclusive education. Such factors may influence the opinions of teachers and the paper aims to reveal whether exist sany connection and, if so, the paer aims to discovery precisely what is the nature of this connection.

Several studies have been conducted in the world related to teachers'attitudes towards inclusive education, for example, the study conducted in Malaysia. In general, the teachers have a positive perception about the implementation of inclusive education, although should be made improvements in some aspects such as the cooperation between teachers in mainstream schools and special school teachers and the training of the teachers that teach students with special needs (Ali M.M., Mustapha R. Jelas Z.M., (2006) An empirical study on teachers'perceptions towards inclusive education in Malaysia, International Journal of Special Education, Vol 21 No3).

Another study was conducted in Canada. The teachers have positive attitudes about inclusive education and about the benefits that disabled students have in the proces of inclusive education. The teachers, on the other hand, think that have inadequate professional preparation to teach these students. Disabled students benefit both in terms of the social plan and in terms of academic level (Bunch G., Finnegan K. (2000), Values Teachers Find In Inclusive Education, ISEC).

Another study was conducted in Hong Kong. The results of this study show that teachers who teach in secondary school do not have favorable attitudes about the practice of integration. Though the most of the teachers $(79,3 \%)$ support the basic principle of inclusive education that every child has the right to learn in a typical class, only $42,4 \%$ of them considered favorable the integration process and $37,9 \%$ think that this process can be successful. The results showed a small, but significant difference in the attitudes of teachers that had received training and teachers that had not received training. The teachers that had received training showed more postive attitudes toward inclusive education (Yuen M. \& Westwood P. (2001), Integrating students with special needs in Hong Kong secondary schools : teachers's attitudes and their possible relationship to guidance training, International Journal of Special Education, Vol 16, No.2). 
Another study was conducted in Chester city, in Pennsylvania. Results of the study showed that the teachers generally have a neutral attitude to integration. Female teachers have more positive attitudes than male teachers, but such a relationship is not significant. There is a difference in the attitudes of teachers of different ages. The teachers under 36 years of age have significant positive attitude towards inclusive education compared to the teachers of other ages involved in the study. The teachers that had experience in teaching children with special needs have more positive attitudes ( (Kern E. (2006), Survey of Teacher Attitude Regarding Inclusive Education Within an Urban School District, Philadelphia College of Osteopathic Medicine).

According to the study conducted in Russia by Elena Iarskaia-Smirnova in 2001-2002, "the opinion of the stakeholders of the education systems, teachers, parents and children, is favorable in the relation of the idea of inclusion as a project. At the same time, when it comes to real life situations, some concerns arise that prevent integration of the child" (larskaia-Smirnova E. 2001/2002, Creating Future Together:Problems and Perspectives of Inclusive Education in Russia", CPSI International Policy Fellowship Program, pg.24).

\section{Theoretical Treatment}

The practice of including students with disabilities into regular schools has been gaining ground internationally for many years now, but is far from being fully accepted by the educational community (see Yellin et al., 2003). For over three decades, researchers have concluded that the degree to which inclusion is successful depends largely on the attitudes and willingness of educators at the school level to welcome and involve students with disabilities in their classrooms in a meaningful way (Avramidis \& Norwich, 2002; Forlin, 2001; Harvey \& Green, 1984; Sharma, Forlin, Loreman \& Earle, 2006; Williams \& Algozzine, 1979) (Loreman T., Forlin Ch, Sharma U (2007), An International Comparison of Pre-service Teacher Attitudes towards Inclusive Education, Disability Studies Quarterly, Volume 27, No.4).

The success of inclusion depends on the attitude of the people involved in its implementation. Teachers' and head teachers' attitudes are a determining factor in the success of disabled students' inclusion in the mainstream school (Norwich 1994; Padeliadu \& Lamproboulou, 1997) (Phtiaka H.(2005), Children with special needs in the ordinary classroom:teachers' and peers' views, Inclusive and Supportive Education Congress, Glasgow, Scotland).

Inclusion largely depends on teachers' attitudes towards pupils with special needs and on the resources available to them. In quite a number of studies, the attitude of teachers towards educating pupils with special needs has been put forward as a decisive factor in making schools more inclusive (Meijer C.J.W. (2001), Inclusive Education and Effective Classroom Practices, European Agency for Development in Special Needs Education, Martin Noble Editorial/AESOP, pg.10

It is now well established that teachers' beliefs and attitudes concerning students with special needs have a very powerful influence on their expectations for the progress of such children in mainstream schools (Deisinger, 2000; Minke, Bear, Deemer \& Griffin, 1996; Odom, 2000; Scruggs \& Mastropieri, 1996). It is even argued that successful integration is only possible where teachers display reasonably positive and accepting attitudes towards students with special needs and to the basic principles of inclusion (Beattie, Anderson \& Antonak, 1997; Freagon \& Kachur, 1993; Giangreco, 1996) (Yuen M., Westwood P. (2001) Integrating students with special needs in Hong Kong secondary schools : teachers' attitudes and their possible relationship to guidance training, International Journal of Special Education2001, Vol 16, No.2, pg.72)

Indeed, teachers' attitudes have been found to affect the process and the outcome of inclusion to a great extent (e.g., Avramidis et al., 2000; Richards, 1999) (Efrosini K., Gojkovic D., Tsakiris V. (2007) Serbian teachers's attitudes towards inclusion, International Journal of Special Education, Vol 22 No 3, pg.30).

Teachers' attitudes and beliefs are known to influence their teaching practices and management strategies in the classroom, and therefore to directly influence students' learning (Garvar-Pinhas \& Schmelkin, 1989; Nader, 1984; Smith, 2000; Winter, 1995). In particular, a teacher's beliefs about the learning capacity of a student with disability may determine the extent to which the teacher is willing to make adjustments to teaching method, curriculum, or classroom organization, or indeed whether he or she even recognizes that some students in the class do have special needs (Fields, 1995; Salili, 1999; Westwood, 1995). It is now generally accepted that teachers who are required to integrate students with disabilities into their classes must feel confident in their own ability to cope with the situation, and must have some positive expectations about the students' learning potential (Forlin, 1998; Webster, 1999). (Yuen M., Westwood P. (2001) Integrating students with special needs in Hong Kong secondary schools : teachers' attitudes and their possible relationship to guidance training, International Journal of Special Education2001, Vol 16, No.2,pg.72).

Teachers with positive attitudes toward inclusion have been found to not only employ instructional strategies that 
benefit all students in a classroom (Bender, Vail \& Scott, 1995; Brophy \& Good, 1991), but have also been found to have a positive influence on the attitudes of peers without disabilities towards students with disabilities (Baker \& Gottileb, 1980; Norwicki \& Sandieson, 2002). (Loreman T., Forlin Ch, Sharma U (2007), An International Comparison of Pre-service Teacher Attitudes towards Inclusive Education, Disability Studies Quarterly, Volume 27, No.4).

\section{Methodology of preparation and development of this paper}

\subsection{Aims and objectives of the paper. The main aims and objectives are :}

- Measuring the attitudes of teachers toward the mainstreaming process.

- Analyzing the influence of the presence of the demographic factors (such as gender, age, educational level (elementary school/secondary school), work experience, working position (teacher/teacher principal) on teachers' attitudes towards : a)the effects of mainstreaming on the academic progress of both disabled and non disabled pupils; b)the negative effects on social and emotional development of segregating disabled pupils in special classrooms.

The aims and the objectives of the paper are related to theoretical treatment and, are related also, to the studies about teachers's attitudes toward mainstreaming. For the realization of this study it is employed a combined methodology. It is used the survey technique. The measuring instrument is the Mainstreaming Opinionnaire (Schmelkin, 1981) to measure teachers'atitudes.towards inclusive education. It is also employed the technique of interviewing teachers of public schools in which there are integrated disabled pupils for the purpose of obtaining their opinions related to the existence of necessary conditions to teach them.

\subsection{Sampling}

The people group in this study consists of teachers from public elementary schools in the cities of Shkodër, Lezhë, Kukës, Peshkopia, Tiranë, Elbasan, Durrës, Korçë and Vlorë. There are used statistics from the General Regional Offices of Education to identify the schools which have pupils with disabilities and to identify the classes in which such pupils have been integrated. The inclusion of the subjects has been realized with respect to the ethical principles that should accompany this process, without forcing anyone into this process and having the permission of the respective authorities. The sample for the study consists of teachers who teach in these public schools. The inclusion criteria include: a)being a public school teacher, b)being involved teachers with different age, c)being involved both male teachers and female teachers, d)involving both teachers and principal teachers, e)involvement of teachers who teach in elementary school and teachers who teach in secondary school, f)the involvement of teachers who have 1-5 years of teaching experience, as well as teachers who have over 20 years of teaching experience. The exclusion criteria include: a) failing to meet at least one of the inclusion criteria, b)the refusal of permission for teachers'partecipation in the study from the General Regional Offices of Education, c) the refusal of permission for teachers'partecipation in the study from the respective schools, d)teachers'refusal to be part of the study.

\subsection{General data related to the teachers who have completed the MO test}

In the study, we had the participation of 408 teachers by completing the MO test. 50 teachers or $12,3 \%$ of the teachers participating in the study live in Shkodra city, 40 teachers $(9,8 \%)$ live in Lezha city, 31 teachers $(7,6 \%)$ live in Peshkopia city, 59 teachers or $14,5 \%$ of the teachers participating in the study live in Kukës city, 34 teachers (8,3\%) live in Tirana city, 51 teachers $(12,5 \%)$ live in Elbasan city, 48 teachers $(11,8 \%)$ live in Korça city, 56 teachers $(13,7 \%)$ live in Durrës city and 39 teachers $(9,6 \%)$ live in Vlora city. The teachers are of different ages. 10 teachers $(2,5 \%)$ are aged 21-25 years, 60 teachers $(14,7 \%)$ are aged $26-30$ years, 49 teachers (12\%) are aged 31-35 years, 77 teachers (18,9\%) are aged 36-40 years, 68 teachers $(16,7 \%)$ are aged $41-45$ years, 42 teachers $(10,3 \%)$ are aged $46-50$ years, 39 teachers $(9,6 \%)$ are aged $51-55$ years, 61 teachers $(15 \%)$ are aged over 55 years, and 2 teachers $(0,5 \%)$ haven't given their age. In the study partecipated 53 male teachers (or $13 \%$ of teachers participating in the study) and 352 female teachers $(86,3 \%)$, while 3 teachers $(0,7 \%)$ haven't given their gender. 167 teachers $(40,9 \%)$ teach in elementary school and 228 teachers $(55,9 \%)$ teach in secondary school, while 13 teachers $(3,2 \%)$ haven't given their teaching cycle. 74 teachers $(18,1 \%)$ have $1-5$ years of teaching experience, 44 teachers $(10,8 \%)$ have $6-10$ years of teaching experience, 50 teachers $(12,3 \%)$ have $11-15$ years of teaching experience, 78 teachers $(19,1 \%)$ have 16-20 years of teaching 
experience, 161 teachers $(39,5 \%)$ have over 20 years of teaching experience, and 1 teacher $(0,2 \%)$ has not given his years of teaching experience. 26 teachers $(6,4 \%)$ are teacher principals, $375(91,9 \%)$ are teachers and 7 teachers $(1,7 \%)$ haven't given their work position.

\subsection{General data concerning the teachers and directors who were interviewed and have participated in the focus-group}

There have been 69 interviews and one focus-group. There are interviewed teachers from the cities of Shkodër, Lezhë, Kukës, Peshkopia, Elbasan, Durrës, Korçë, Vlora cities. The focus group is organized in Shkodra city and in the focusgroup have participated six teachers of Pashko Vasa primary school.

\subsection{Apparatus / Materials}

With the teachers it is employed the Mainstreaming Opinionnaire (MO) (Schmelkin, 1981) to measure their attitudes towards the inclusive education. It is found in the book Antonak R.F., Livneh H.(1988) "The Measurement of Attitudes toward People with Disabilities", USA, page 256-262).

\subsection{Contents of the questionnaire}

A total of 30 items were retained with 15 items scored on each of the two subscales. The first Subscale, Academic Cost of Mainstreaming (ACM), concerned the detrimental effects of mainstreaming on the academic progress on the academic progress of both handicapped and non-handicapped students. The second Subscale, Socio-Emotional Costs of Segregation (SECS), concerned the negative effects on social and emotional development of segregating handicapped children in special classrooms (Antonak R.F., Livneh H.(1988) "The Measurement of Attitudes toward People with Disabilities", USA, pg.256).

\subsection{Method of completing the questionnaire}

The questionnaires have been filled out by the teachers themselves. The questionnaires were distributed in the respective schools. The administration of the questionnaires (distribution and collection) was conducted during the months of September, October, November and December.

\subsection{Method of analysis}

The data collected from the questionnaires was analyzed by means of the SPSS program, variant 20. It is estimated the reliability of the test. The internal reliability of $A C M$ Subscale Alpha Cronbach coefficient $=0,834$. The internal reliability of SECS Subscale Alpha Cronbach coefficient $=0,822$. It is carried out the coding of the variables according to the respective rules defined by the authors. There are created respective indexes according to the guidelines.

Each of the 30 items on the $\mathrm{MO}$ is responded to on a six-point scale, ranging from -3 , to signify "Disagree very strongly", to +3 , to signify "Agree very strongly". To score the MO, the value of four is added to each response. This transforms all values to a positive whole number from 1 to 7 (eg., $-3=1,-2=2,-1=3$, missing=4, $+1=5,+2=6$, and $+3=7$ ). The respondent's score on the ACM subscale is calculated by adding the responses to the items : $1,3,4,8,9,10,12$, $16,18,19,20,26,27,28$, and 30 . The total is divided by 15 to yield a mean value ranging from 1 to 7 , with a low value representing a positive attitude toward this aspect of mainstreaming. The respondent's score on the SECS subscale is calculated by adding the responses to the remaining 15 items : 2, 5, 6, 7, 11, 13, 14, 15, 17, 21, 22, 23, 24, 25, and 29). As with the first subscale, a mean value is calculated by dividing the toatl by 15 , with the result ranging from 1 to 7 . A postive attitude toward this aspect of mainstreaming, however, is reflected by a high score (Antonak R.F., Livneh H.(1988) "The Measurement of Attitudes toward People with Disabilities", USA, pg.257).

It is used the analysis of variance Anova table and eta to examine the impact of teachers'demographic factors (as teachers'gender, educational level, teachers'work position, teachers'work experience) on the ACM and SECS results. It is used the correlation method to examine the impact of teachers'age on the ACM and SECS results. 


\subsection{Content of the interviews and focus-group}

The contents of the interviews and focus-groups was thought in a way as to collect the opinions of teachers concerning: 1) the indicators of the structure, 2) the indicators of the learning process. In relation to the structure indicators the paper aims to obtain the teachers'opinion about: a) the human resources, such as the number of student per class, the existence of the supportive teacher, teachers'involvement in qualification processes about disability, the existence of other support staff at the school, etc,; b)the structural resources, such as: the existence of laboratories for the disabled students in the school, the existence of the necessary space for them, the existence of didactic matherials needed to teach disabled children. In relation to the indicators of learning process, the paper aims to obtain the teachers'opinion about: a) the existence of an individualized education plan for the disabled student, b)the relationship between schools and other support institutions, c)the relationship between the school and other schools.

\subsection{Piloting stage}

It is realised the piloting phase. In this phase the internal reliability of MO opinionnaire Alpha Cronbach coefficient=0,812. It is not evidenced any item of the opinionnaire that has low reliability. So, the realization of the study was possible. The dependent variables are the ACM and SECS scores. The independent variables are teachers' demographic factors.

\section{Findings of the study}

4.1 Data obtained from the first subscale, Academic Cost of Mainstreaming (ACM) and from the second subscale, SocioEmotional Costs of Segregation (SECS)

The data obtained are illustrated in Table 1.

Table 1. Data obtained for ACM and SECS subscales

\begin{tabular}{|c|c|c|c|c|c|c|c|}
\hline & N & Mean & Median & Mode & $\begin{array}{c}\text { Standard } \\
\text { deviation }\end{array}$ & Minimum & Maximum \\
\hline ACM & 408 & 4,55 & 4,53 & 4,53 & 0,96646 & 1,40 & 6,87 \\
\hline SECS & 408 & 4,61 & 4,63 & 5,13 & 0,91707 & 1,93 & 7 \\
\hline Valid & 408 & & & & & & \\
\hline
\end{tabular}

Regarding the ACM subscale, the mean is 4,55 . This fact indicates that, in general, teachers have not a good attitude concerned the effects of mainstreaming on the students' academic progress. The values range from $1,40(0,2 \%$ of the teachers participating in the study), to $6,87(0,2 \%$ of the teachers partecipating in the study). The most of the obtained results is ranked in the range of values from 4 to 6,87 (301 teachers or 73,8\%), while a small fraction of the values obtained ranged in the range of values from 1,40 to 4 (107 teachers or $26,2 \%)$.

Regarding the SECS subscale, the mean is 4,61 . The values range from $1,93(0,2 \%$ of the teachers partecipating in the study) to $7(0,2 \%$ of the teachers participating in the study). So, the teachers, in general, have positive attitude about socio-emotional costs of segregation. The most of the obtained results is ranked in the range of values from 4 to 6 (270 teachers or $66,1 \%$ ), while a small part of the obtained values is ranked in the range of values from 6 to 7 (28 teachers or 6,9\%).

\subsection{The analysis of the impact of teachers'demographic factors on the ACM and SECS results}

The relationship between the ACM results and teachers'gender is not statistically significant ( $\mathrm{Sig}=0,778)$. The ACM mean for male teachers is 4,52, while for female teachers is 4,56. The relationship between the SECS results and teachers'gender is not statistically significant $(\mathrm{Sig}=0,484)$. The SECS mean for male teachers is 4,69 , while for female teachers is 4,59. The relationship between the ACM results and educational level is not statistically significant $(\mathrm{Sig}=0,595)$. The ACM mean for the teachers who teach in elementary school is 4,52 , while for teachers who teach in secondary school is 4,57 . The relationship between the SECS results and educational level is not statistically significant $(S i g=0,805)$. The SECS mean for for the teachers who teach in elementary school is 4,61 , while for the teachers who teach in secondary school is 4,59. The relationship between the ACM results and teachers'work position is not 
statistically significant (Sig=0,952). The ACM mean for the teachers is 4,55 , while for principal-teachers is 4,54 . The relationship between the SECS results and teachers'work position is not statistically significant $(\mathrm{Sig}=0,469)$. The SESC mean for the teachers is 4,60 , while for principal-teachers is 4,73 .

The relationship between the ACM results and teachers'work experience is not statistically significant $(\mathrm{Sig}=0,879)$. The ACM mean for the teachers with work experience 1-5 years is 4,57 , the ACM mean for the teachers with work experience $6-10$ years is 4,57 , the ACM mean for the teachers with work experience $11-15$ years is 4,59 , the ACM mean for the teachers with work experience 16-20 years is 4,45, while for the teachers with work experience over 20 years is 4,58. The relationship between the SECS results and teachers'work experience is not statistically significant $(S i g=0,142)$. The SECS mean for the teachers with work experience 1-5 years is 4,50, the SECS mean for the teachers with work experience 6-10 years is 4,40, the SECS mean for the teachers with work experience 11-15 years is 4,52, the SECS mean for the teachers with work experience $16-20$ years is 4,62 , while for the teachers with work experience over 20 years is 4,74 .

The correlation between the ACM scores and teacher's age was estimated by calculating the Pearson coefficient and Spearman coefficient. The Pearson coefficient is 0,022 and the Spearman coefficient is 0,012 . So, there is a very low correlation between ACM scores and teachers'age. The correlation between the SECS scores and teacher's age was estimated by calculating the Pearson coefficient and Spearman coefficient. The Pearson coefficient is 0,113 and the Spearman coefficient is 0,118 . The correlation is significant at the 0,05 level. There is a very low correlation between SECS scores and teachers'age.

\subsection{Data obtained from the interviews and the focus-group developed with teachers on the issue of inclusive education}

The teachers have such opinions about the structure indicators: The number of students in the classes where are integrated disabled children is the same, in general, as the number of students in the classes where aren't integrated disabled children. Teachers, in general, think that the number of students in classes with disabled children integrated should be smaller than in other classes. In general, there is not the support teacher in the schools where are integrated disabled students. The teachers appreciate to much the role of the caretaker teacher in their teaching work with disabled children. The teachers appreciate, also, the interaction and the cooperation that exist between them and the caretaker teacher. The teachers, in general, claim they are not recently involved in the qualification processes about disability. They think that need to be trained about disability. There is a psychologist, in general, in the schools. There are schools where there is not a psychologist and the teachers want the presence of the school psychologist. The teachers appreciate the psychologist role in the schools where the psychologist are present. The psychologist helps the teachers in their process of teaching disabled students. There is, also, other auxiliary personnel in the schools, such a dentist and the nurse. The teachers claim that don't exist laboratories for these students. Most of the teachers think that there is no space needed for students with disabilities. Even those teachers who say that exists the needed space, think that this space is not appropriate for disabled students. There is not a resource center in relation to the disability at the schools. The schools libraries have a few books about disability. The teachers, also, think that there are no specific didactic materials to teach students with special needs. The teachers, in some cases, prepare themselves these materials.

The teachers have these opinions in relation to the indicators of teaching process : In general, doesn't exist the individualized education plan for the disabled students, but in some cases it exists. The schools relations with other institutions are good. The teachers appreciate especially the cooperation with the physicians about the various problems of their students. Teachers claim that they collaborate with their colleagues of the other schools. They collaborate with teachers who know each other, but there is not institutional relationship between the schools. The teachers consider as necessary the scholastic integration of disabled students, because their integration makes them feel equal with the rest of society. The teachers, however, argue that the process of inclusive education is accelerated, because there are many difficulties in his implementation and, as a result, a good portion of teachers think that would be better a special school for these students, with the appropriate conditions and with an academic specialized staff.

\section{Conclusions}

In general, the teachers have not a good attitude concerned the effects of mainstreaming on the students'academic progress. They have, in general, positive attitude about socio-emotional costs of segregation. There is not statistically relationship between the teachers'demographic factors and the ACM and SECS results. So, the opinion of teachers about inclusive education is not influenced by these factors. The teachers consider necessary the improvement of the 
structure indicators and the improvement of the indicators of teaching process. The data obtained for our teachers coincide, in general, with the data obtained from some studies conducted in other countries. The common to all of the data obtained is that the teachers, in general, are expressed positively in principle for the inclusive education as a human right, but they are reluctant and they have different views about the implementation of this process. Another common phenomenon noticed is related to their professional training about disability. So, the teachers percept themselves as not very prepared to teach children with special needs.

\section{Recommendations}

Based on the findings of the study and on the conclusions drawn from it, it is necessary to consider the following recommandations so that the process of inclusive education be carried out completely :

- A further awareness of the teachers concerning the integration of the pupils with disabilities into schools as a necessary process.

- A greater involvement of teachers in qualifying processes about disability.

- The reducing of the number of students in the classroms where are integrated students with special needs.

- The employment of supporting teachers in the schools where are integrated students with special needs.

- The equipment of the schools with laboratories and special didactic materials for teaching children with disabilities.

- The establishment of the necessary and appropriate space for disabled students in the schools.

- The equipment of the schools with a resource center and with theoretical books about disability.

- The development of the individualised education plan for students with special needs.

- The improvement of schools relations with each other and with the special schools and the improvement of the quality of this cooperation.

\section{References}

Ali M.M., Mustapha R. Jelas Z.M., (2006) An empirical study on teachers'perceptions towards inclusive education in Malaysia, International Journal of Special Education, Vol 21 No3

Antonak R.F., Livneh H.(1988) "The Measurement of Attitudes toward People with Disabilities", USA

Bunch G., Finnegan K. (2000), Values Teachers Find In Inclusive Education, ISEC

Gherardini P., Nocera S, AIPD (2000) L'integrazione scolastica delle persone Down, Trento, Erickson

larskaia-Smirnova E. 2001/2002, Creating Future Together:Problems and Perspectives of Inclusive Education in Russia", CPSI International Policy Fellowship Program

Kern E. (2006), Survey of Teacher Attitude Regarding Inclusive Education Within an Urban School District, Philadelphia College of Osteopathic Medicine

Loreman T., Forlin Ch, Sharma U (2007), An International Comparison of Pre-service Teacher Attitudes towards Inclusive Education, Disability Studies Quarterly, Volume 27, No.4

Meijer C.J.W. (2001), Inclusive Education and Effective Classroom Practices, European Agency for Development in Special Needs Education, Martin Noble Editorial/AESOP

Nano V. (2002) Shkolla shqiptare drejt proceseve integruese-Studim për integrimin e fëmijëve me aftësi të kufizuara në shkollat e zakonshme, Tiranë

Phtiaka H.(2005), Children with special needs in the ordinary classroom:teachers' and peers' views, Inclusive and Supportive Education Congress, Glasgow, Scotland

Yuen M., Westwood P. (2001) Integrating students with special needs in Hong Kong secondary schools : teachers' attitudes and their possible relationship to guidance training, International Journal of Special Education2001, Vol 16, No.2 